\title{
Intersections Between Education and Health Reforms in Brazil: When the "Target Population" is an Active Builder of the Public Policy
}

\author{
Renata Penalva \\ University of São Paulo (USP) \\ Adriana Marcondes Machado \\ University of São Paulo (USP)
}

\begin{abstract}
This article is an argumentative literature review that discusses the history of the intersections between health and education in Brazil, exploring its connections to segregation practices and, also, to movements towards democratic ideals. We focus on the importance of population participation for the reforms in the health sector, allowing for the construction of the Brazilian Public Health System and health practices that aim to not collude with inequalities. We argue that an ethical posture in public policy consistent with the one proposed by Paulo Freire has incentivized population participation in a way that strengthens the commitment to democracy in public policy. Such ethical posture 1) considers social determinants of the phenomena that happens to an individual, and 2) requires constant effort to not fall for the tempting silencing of one's existence and full citizenship. We comprehend Freire's ethical posture as one that can help build intersectoral actions on public service, facilitating social participation to inform public policy and help improve citizen's well-being. We propose that intersectoral participation spaces can be compelling devices to hear the population's input as an alternative to separating people's experiences in participation Councils of each public sector area.
\end{abstract}

\begin{abstract}
Introduction
Health disciplines have historically been used to justify social differences through "biologization" and individualization of the causes of socioeconomic inequalities (Foucault, 2002). In Brazil and other countries, psychology and psychiatry served to justify racism and school failure, instead of searching for methods to address the multicausality of school failure (Patto, 1990). Within this multicausality, social inequities are a central factor (Patto, 1990, Feinstein, 2003). Pondering social inequities into healthcare policy debates in Brazil contributed, during the democratization process, to opening the discussion on health system changes to the population, leading to structural reforms (Paim, 2006). We understand that the lines of thought and practice that successfully carried a democratic way of reaching critical reforms towards democracy in Brazil's health policies are connected to Paulo Freire's propositions of democratic participation. For Freire, social participation in education was crucial not only for educational engagement purposes, but because participation itself was a sine qua non element to overcome the Brazilian "democratic inexperience" (Freire, 2003) and its high illiteracy rates. Freire (2003) pointed out the social determinants of illiteracy and highlighted the democratic issues in the Brazilian legislation Republic, in which literacy was a criterion for being allowed to vote up until 1985.
\end{abstract}


For the authors from the Brazilian Collective Health movement and other people connected to the Health Reforms in the 1980s, population participation was an essential element to drive policy towards equity and to boost movements of change into having reform and democratic dimensions (Paim, 2006; Ensp Fiocruz, 2016). They also pointed out the social determinants in the health-disease process and considered there would be no democracy without health for all (Paim, 2006). Inspired by those movements, the Brazilian Constitution states that "Health is a right for all and a State's duty" (Brasil, 1988).

This argumentative literature review was composed to collaborate with the discussion of comparative education fields dedicated to understanding the role of education in social transformation (Butts, 1968 apud Wilson, 1994). The role of education in democracy has been an ongoing discussion since the end of the XVIII century up until now (Bueno, 1993; Glaeser et al., 2006). We consider that exploring the historical intersectoral interactions might add layers of understanding to what works or not in guaranteeing democratic processes towards equity in education, as discussed by the comparative education field (Wilson, 1994). This article focuses on presenting parts of the history of the Brazilian Health and Education sectors, giving special attention to the elements that were necessary to convey change towards equity.

\section{Methodology}

This argumentative literature review draws from previous research (Penalva, 2020) that discussed intersectoral actions amongst Mental Health and Education workers. This study was part of an iterative method of developing and informing actions to support the learning process of marginalized students at schools in a peripheric region of São Paulo, Brazil. The bibliographical review's purpose was to provide historical data to these intervention questions: 1) "how can workers from mental health disciplines collaborate with educators for an inclusive education?" 2) "and how can they achieve that without silencing social processes?".

These questions arose from the observance of issues in the communication and not-socombined actions between health and education workers who assisted the same children and adolescents. The non-encounters between these professionals resulted in the loss of opportunities to create gathered strategies to diminish school failure (Penalva, 2020). We then decided to research how intersections between Education and Health could collaborate with inclusion and mitigate educational inequities (Penalva, 2020).

This literature review was non-structured and based on the search for authors that 1) critically explained the historical role psychology and psychiatry have in justifying school failure (Foucault, 2002) and/or 2) proposed changes that respected teachers and considered multi determination of school processes (Angelucci, 2014; Machado, 2016). The final bibliography comes from field specialist recommendations, research of core Brazilian national literature on the fields of School Psychology (Patto, 1990), Collective Health (Paim, 2006), Mental Health (Tenório, 2002), Education (Freire, 1987) and Special Education (Mendes, 2010; Bueno, 1993, Angelucci, 2014), and from non-structured literature review. 


\section{Psychology and psychiatry historical background as contributors for educational segregation and oppression}

By the second half of the 19th century, the bourgeois model of society had not fulfilled its promise of equal opportunities for all. In this promise, the school was an important piece at play, considered as a solution to placate economic, social, and cultural differences (Patto, 1990; Machado, 1996; Machado, 2016; Patto, 2017). In 1857, Morel published a thesis on degeneration, creating a biological justification for lower social classes and specific phenotypes to be considered inferior (Foucault, 2002). Morel proposed a biological and hereditary basis for the "immoral" behavior, strengthening the connection between psychiatry and the judiciary systems - in which psychiatry would tell the judiciary if there was something "monstrous" about the suspect for them to be convicted. Through this perspective, differences created by historical exploitation were understood as having been caused by individual and biological features (Navarro, 2010; Foucault, 2002).

Later in the 19th century and the beginning of the 20th century, psychiatry, mainly represented by the name of Bourneville, and psychology with Binet and Simon, created the practice of classifying children. These classifications defined which types of children would be allowed to study in regular schools and which would be directed to asylums and special education schools (Bueno, 1993). Binet and Simon created an intelligence scale and test, defining intelligence in a specific way and circumscribing the concept to the Psychology field (Nicolas et al., 2013). This test did not measure solely biological features, and the ones who created it also remarked the social aspects of intelligence. Nonetheless, their remarks remained circumvented as a warning, and the intelligence test started to be used to determine who was to be considered abnormal or be in regular schools (Machado, 1996; Patto, 2017).

In Brazil, different medical and psychological services would define, throughout the 20th century, who was to be in special education and how special education would function. Nonetheless, the method to classify who was abnormal could commonly be the "scholarempirical" method, in which the medical field used the school report to determine who would be their students or not. A 1904's Law determined that the "incapable of receiving education" would not be registered for formal education (Januzzi, 2012). It was a circular model that legitimized and fostered segregation.

Throughout history, we see these intersections between mental health disciplines and education as varying amongst two different lines of thought/practice, but that do not necessarily oppose each other. The first line of thought categorizes potential students to better insert them in education, whereas the second one categorizes to segregate. Both of them focus attention on the student, not on the educational system and its relation to society's structures. The first line of thought/practice goes back to Jean Marie Gaspar Itard, who published L'Éducation d'un Homme Sauvage (in English, "The Education of a Wild Man"). This text was considered the first publication about the education of a person with intellectual disability, in which he describes the experience of educating the "the wild man from Aveyron" - the "sauvage d'Aveyron" - (Januzzi, 2012). Itard opposed himself to what we consider here as the second line of thought/practice: the one of Esquirol and Pinel $^{1}$, who believed that "idiocy" was irreversible and that the "sauvage d'Aveyron" was untreatable. Categorization would serve to designate places where people could circulate - either regular schools, special education schools, or asylums. Along the first line of thought, Itard's line, there are names like Seguin or Montessori, who believed good prognostics could come with specific methods (Marfinati \& Abrão, 2014). The German

${ }^{1}$ Esquirol and Pinel were the ones that argued that madness was not a crime, but treatable (Bueno, 1993).

They "released" the ones considered mad from prisons... but enclosed them in psychiatric asylums. 
school of psychiatry was more aligned to Pinel. Both these lines of thought and practice had an important influence in Brazil.

The "trend" begun by Morel on biological explanations for social differences set the origins of eugenics, proposed by Francis Galton as a "science" for the "improvement of the race" (Navarro, 2010). Such thinking only became officially considered a pseudoscience after the end of the Second World War (Verzolla, 2017). During Hitler's Reich, eugenic laws allowing for "sterilization of the degenerate" people and "merciful death" for the "mentally ill" were installed from the beginning (Navarro, 2010).

Not only in Germany, but in other countries, attention was turned to how to prevent "degeneration". Thus, childhood started to be more debated in the Psychiatric field. Such eugenic thinking heavily influenced certain groups of psychiatrists and psychologists in Brazil during the 1920s and the 1930s. Specifically, the Brazilian League of Mental Hygiene (Liga Brasileira de Higiene Mental -LBHM), funded in 1923. The LBHM started their work assisting the "mentally ill". Later, in the 1930s, they began to direct themselves towards practices and advocacy for "prevention" of "degeneration" in the name of "the nation's future" (Costa, 1980). For them, children from lower classes were naturally more prone to "delinquency" and needed special focus. Prevention actions would entail, for instance, institutionalization, "crusades" against alcoholism, propositions of sterilization of the "degenerate", and criticism on religion and philanthropy "that helped the physical, psychic degenerates and criminals to live and thrive" 2 (Kehl apud Costa, 1980). They would also recommend European immigration and miscegenation among races in Brazil to "whiten" the population (Costa, 1980) and "improve" the nation. This type of theory constitutes a strong trait in the history of racism in Brazil.

On the other side, there were also Mental Hygiene Services that focused on the social causes of what could be in the way of a child's access to education. But the phenomenon of mental health ruling about ideal actions in other fields of knowledge was still similar. These other Mental Hygiene Services were associated with the New School movement in Brazil and advocated for school access to reach democratic ideals. As health professionals, they provided recommendations for parents and teachers. Still, they focused their actions mainly on psychologically understanding the students to recommend educational actions for inclusion, rather than restructuring the educational system. These were the Service of School Mental Hygiene (Serviço de Higiene Mental Escolar), created in 1938 in São Paulo and directed by Durval Marcondes, and the Service of Ortofreny and Mental Hygiene (Serviço de Ortofrenia e Higiene Mental), created in 1934 and ran by Artur Ramos in Rio de Janeiro (Garcia, 2014).

Durval Marcondes's service offered child evaluation and parents' and teachers' orientation. There were also written reports in which Durval Marcondes addressed schools, by recommending the importance of meal providence to kids in school or guiding special education services, for example. The interventions with the family had a hygienic conduct code imposition that was external to the people cared for in the service (mothers should be caring, fathers should be an authority). Arthur Ramos in Rio de Janeiro had more focus on children that were considered aggressive and recommended changes in the children's immediate environment, such as telling the parents not to beat their children. Ramos talked about the subjective consequences of racism and recommended teachers to incite kids to talk in school for their wellness, based on the psychoanalytic idea of talking cure (Garcia, 2014, Freitas 2009).

\footnotetext{
${ }^{2}$ The translation was made by the authors of the present paper.
} 
Arthur Ramos was invited to direct his service in Rio de Janeiro by Anísio Teixeira, the main name in Brazil regarding the New School movement and John Dewey's ideas. Anísio Teixeira had an important position in the 'Education for All' movement in Brazil and advocated that education was the basis and most important public sector area to improve for a true democracy with equal opportunities to be built (Teixeira, 1956).

Similar to Anísio Teixeira, Helena Antipoff, a Russian psychologist from Sorbonne, was an important name in Brazil New School thinking. She believed in school as a social transformation factor and that it was vital to know the "nature" of every student to plan pedagogical activity for each of them. As a professor in a College for Teachers in Minas Gerais, she advocated that all kids could go to school, in opposition to laws that disobliged to do so the ones who did not have such possibility. Possibility meaning what was considered intelligence aptitude, but also living close to a school. As a solution, she introduced the practice of different classrooms with homogeneous students considering scholar aptitudes, measured by psychological tools (Campos, 2009). This model was spread in Brazil during the 1950s and became a tool that collaborated with segregation. Artur Ramos's propositions also suffered a backlash. Trying to dislocate the idea that children from lower social classes were "delinquent-children", he coined the term "problem-children" (in Portuguese, criança-problema) to denunciate the violence, injustices, and oppression they suffered. The term "problem-child" became almost a diagnostic itself, a label in schools to talk about children that would cause trouble to the school and probably fail (Freitas, 2009), justifying the future school failure in a selffulfilling prophecy functioning.

Segregation through special education classrooms continued to exist in Brazil until the 2000s. From the 1980s forward, groups of psychologists started to expose more intensely how multiple factors that acted upon the relation student-school were being ignored, and only students' features were considered when justifying school failure (Patto, 1990). Especially, they uncovered how most of the students that were classified as having a mild intellectual disability and were referred to special education were prevalently from low socioeconomic status, questioning the way this diagnostic is built (Machado, 1996; Patto, 1990; Machado, 2016; Patto, 2017), and showed how difficult it was for special education classrooms to have any connection to what the regular education classrooms were (Machado, 1996). Special education classes had a curriculum that strongly consisted of manual activities to "prepare" for alphabetization (Mendes, 2010), an alive heritage from Dr. Bourneville's methods (Muller, 2000), and served more to intensify social marginalization than to increase educational achievement options (Bueno, 1993; Mendes 2010).

In 1985 when Brazilian democracy was restituted, 25\% of the Brazilian population was not able to read. Up until then, not reading meant not being allowed to vote (Westin, 2016). Educational marginalization was deeply connected to the lack of full citizenship. In 1964, when Paulo Freire was working with adult literacy, more than half of the population could not read or vote. The president at that time, João Goulart, wrote in March of 1964 to the Congress about voters not representing the whole nation fairly (Westin, 2016).

On April $1^{\text {st }}$ of 1964, a military coup overthrew João Goulart from the presidency, and with United States' active support, a two-decade military dictatorship was installed in Brazil. The first military president after the coup, Castello Branco, was present at the 
celebration at the end of Paulo Freire's 40 hours experience of Angicos ${ }^{3}$ in June of 1963. So was João Goulart, who read the letters of the recently-literate graduates during the ceremony. One of them mentioned that the experience not only had taught them how to read the $\mathrm{ABC}$ but also how to change it. On that day, Castelo Branco commented that Paulo Freire was "teaching a pedagogy with no hierarchy" (SescTV, 2020). Paulo Freire had to leave the country during the dictatorship.

\section{Paulo Freire, Democratic Education, and Collective Health: public policy de-alienation and participation}

Access to education was literally connected to citizenship in Brazil. Freire's proposition to consider the underlying social determinants that are present in the act of education and base the lesson in a dialogue with the students instead of "categorizing" them - constitutes an ethical position that deeply influenced other sectors, such as the Health sector. We will briefly explore some of these relations and later discuss the 1980s Brazilian Health movements, which led to the restructuring of mental health assistance and the creation of the only Public Health System of continental-size in the world.

Paulo Freire talked about political rights and the importance of what the workers created in the world while he was teaching them how to read words. In his perspective, these elements were connected in the most visceral sense. Paulo Freire's approach in Angicos consisted of an objective method, built from years of education experience based on dialogue and working with adults. Experiences, for instance, such as the Cultural Circles ("Círculos de Cultura") at the Movement of Popular Culture from Recife, in which the adult education was based on discussions the students chose to have and where themes like "Brazilian political evolution", "Right to vote and illiteracy", "Development" and "Profit outflows" commonly appeared (Freire, 2003).

From these Cultural Circles, he started to try similar experiences with alphabetization. The result was a careful procedure that considered what made sense to people who would have worked all day before class. Senseless words from an out-of-context and pre-done cart would not engage. Contextless words also did not collaborate to overcome neither illiteracy in Brazil nor the country's "democratic inexperience" (Freire, 2003). The method consisted briefly of ${ }^{4}$ :

1) Listing, through informal meetings, of the most used words by the students. This would also build the relationship between educators and students;

2) Selection of the words based on phonemic richness, phonetic difficulties that match the language difficulties, and word usage level (to incite better engagement). The selected words became the "generator words";

3) Creation of problem-situations based on typical local experiences that provoke analysis of regional and national problems, to be discussed in the groups;

4) Building scripts to support coordinators to spur the debate;

\footnotetext{
${ }^{3}$ The experience of Angicos: Angicos was a city in the Brazilian northeast with a high rate of people that could not read. In 1963, Paulo Freire and a team of 19 university students, with the great support of the university and the government, went on an excursion to the city to offer a 40-hour course. Over 300 people participated. Up until today, we can access testimonies of the people who learned how to read in that experience.

${ }^{4}$ This is a very simplified scheme of the method. To understand it better, please read Freire (2003).
} 
5) Making notes of the decomposition of the phonemic families that correspond to the generator words;

6)Practical execution: a real-world problem is pictured on the board and presented for the students. They discuss it, the word connected to it is visualized, and its semantic link to the discussion is exposed. Right after, the word is exposed in syllables, and the student recognizes the chunks. The same procedure is repeated, but now with phonemes, showing the phonemic family of each of the chunks, what leads to understanding the vowels (the example given by Freire (2003) is about the word brick - ti-jo-lo: phonemic families are shown for each of the syllables (ta-te-ti-to-tu, ja-je-ji-jo-ju, la-le,li,lo,lu) and, from there, new words can be built and discovered by the student. Freire gives the example of a man who wrote "tu já lê" from this exercise, which means "you already read").

There are two levels of participation to be looked at here in this example. One is a more micro level: student participation is needed for the objective of the teaching activity to be successful. Participation is not just used because it is "correct", it is the bulk of the work that does not fulfill its objective without participation. In addition, there is the second participation to be looked at: democracy would not be representative without more adult learning. Learning to read words and learning about their actions in the world. To change the social structure that placed Paulo Freire in the social position he occupied in relation to the adults he taught, the dialogue was vital, their participation was needed. Society would be more if they were more, as Freire points out in the Pedagogy of the Oppressed (1987). But to guarantee true dialogue with them, Freire reports that constant based-ondialogue-supervision of the coordinators was needed, as it is very tempting to enter an anti-dialogue posture (Freire, 2003). It can be easy to silence the other and move on with the "teaching-task". But if this happens, the aim of the task is lost along the way.

We understand this posture is also present in the construction of the Collective Health field in Brazil, which ultimately collaborated with the Sanitary Reform that helped build the Brazilian Public Health System (Sistema Único de Saúde - SUS). Collective health is an interdisciplinary field of knowledge (Paim \& Almeira Filho, 1998) that began in Brazil in the 1970s. It makes an inflection in the Public Health field by denying the monopoly of knowledge in Health to the biological disciplines (Birman, 2005). The variation that comes with changing the name "Public" for "Collective" removes the hegemonic power of the State to regulate life, giving importance to social life (Birman, 2005).

Historically, collective health is inspired by two fields coming from North America: preventive medicine and community medicine. The principles of preventive medicine, which had been more present in economically central countries, came to Latin America through the Seminars of Viña del Mar (1955) and Tehuacan (1956) with the support of U.S. foundations and the Pan American Health Organization (Paim, 2006). In their arrival to Latin America, community medicine and preventive medicine were merged, resulting in the opening of departments of medicina preventiva (preventive medicine) in the colleges of Health, mainly during the 1960s.

In the United States, community medicine was a movement dedicated to caring for the impoverished population who were not covered by private medicine (Rivera, 1989). Preventive medicine was the one that brought the notion of integrality and criticized the fragmentation of medical specialties. Its theoretical basis is the natural history of diseases of Leavell and Clark (1965 apud Arouca, 1975), which initiated a discussion on the 
multicausality of diseases and different levels of health care for different moments of illness, in an attempt to rearrange medical care so that the State would be responsible for primary care. In this proposition, prevention and health promotion are considered primary care; treatment and prevention are secondary care, and intensive treatment is tertiary care. This movement propositioned to inculcate values of preventive and social order in the medical body through medical schools, understanding the doctor as an actor of change in society (Paim, 2006). At the same time, this arrangement forged the idea of planning in medical schools with optimization of resources and reduction of costs. In Brazil, it was from the courses of medicina preventiva (preventive medicine) that the field of collective health was created in the 1970s in an effort to de-alienate health, broadening its definition (Paim, 2006).

In 1978, the Alma-Ata Conference reaffirmed that health should no longer be seen as the absence of disease but as "a state of complete physical, mental and social well-being". Additionally, it states that inequality in health between developed and developing countries is unacceptable and reiterates the commitment of Health for All in the 2000s (from 1977). Finally, it emphasized Primary Care as an essential health strategy and the importance of action in other sectors.

In alignment with the world trend, the conceptual mark of collective health is considered to be the "overcoming of the dominant biologism, of the naturalization of social life, of its submission to the clinic and its dependence on the hegemonic medical model" (Paim \& Almeira Filho, 1998, p. 310). Collective health widens the health field by incorporating new disciplines and considering the social determinants in the health-disease process (Paim, 2006). Due to the importance that social determinants have in collective health, and considering that, by the 1980's, inequalities were being broadened by a Brazilian Health System that only provided health care to formal workers, the discussion about health improvement was soon connected to the debate about democracy.

Influential authors that contributed to the construction of Collective Health as a field of knowledge would cite Paulo Freire or other education authors, like Demerval Saviani, an author that proposes an emancipatory education to overcome an education that maintains inequalities. One of these collective health "builders", Joaquim Alves Cardoso de Mello (Zancan \& Matilda, 2015), for instance, argued in 1986 that health education should not be focused on teaching the population not to get ill, as this position would entail that it is their individual responsibility for getting sick. Such a position was not coherent in a country where an enormous part of the population did not have access to a sewage system, while $10 \%$ of Brazilians possessed $50 \%$ of the country's wealth (Mello \& Valla, 1986). So, for Cardoso de Melo, Health education would better fit Brazil's reality if it focused on issues such as agrochemicals, pollution, and human rights claims. This type of discussion was not the newest in the Health sector. However, now, it was boosted with different understandings of what was needed to build democratic practices and had the names of Freire and Saviani consistently being cited. In health professionals' formation, Paulo Freire became an author with considerable importance (Silva et al., 2020).

\section{Sanitary reform and mental health reform: participation that drives change}

We have briefly gone through some Brazilian propositions and movements in the education and health sectors during the 1960s, 1970s and 1980s. However, a more thorough depiction of how Brazil was and how reforms happened calls for a succinct description of the military government's performance in these areas. 
In education, the government had forsaken its responsibility towards Special Education. The increase in the number of dropouts and school failure was being linked to theories of mild intellectual disability and reinforced the justifications for creating special classrooms (Mendes, 2010). The discourse "for all" was not enough to guarantee that everyone would have an education. The major portion of special education classrooms and schools were administrated by private institutions or family associations, traversed by a strong speech of philanthropy instead of the one about rights and citizenship (Mendes, 2010).

In public health, the sanitary crisis contrasted with the alleged "economic miracle" declared by the military government. Infant mortality rates were high, access to health care was difficult, labor accidents had increased, endemics were strengthening, and a meningitis epidemic had been set in place (Paim, 2007).

In mental health, psychiatric asylums were a revenue business for private institutions, in which the government paid such institutions to care for the patients. If the patients never got cured (stayed for as many days as possible), if their number was higher, and if these institutions could decrease the costs with technology and professionals, this meant more guarantee of profit. This scenario generated atrocious dehumanization situations, including torture, silencing, and abandonment (Tenório, 2002). Until the end of the 1970s, there was consistent criticism of the psychiatric asylum models, especially after the deflagration of frauds in the partnerships with private institutions.

What became known as the Brazilian Mental Health Reform also heated up with the struggle for a democratic society: until 1978, the movements against the working mental health care in Brazil were mostly composed of workers that criticized privatization, overcrowding, and mistreatment, but did not argue so strongly against the psychiatric asylum model itself (Tenório, 2002). In 1979, there was an event in Brazil with Basaglia and Castel $^{5}$, which impacted workers' movements. They began to intensely criticize the asylum model itself and gathered with family members and users ${ }^{6}$ of the mental health system. Combined, these three categories formed the Anti-asylum Struggle Movement (Movimento da Luta Antimanicomial - MLA) by the very end of the 1970s and the beginning of the 1980s (Nader, 2017). "Social inclusion" began to appear in the worker's vocabulary (Dunker \& Kyrillos, 2015). Their main claim became the citizenship of the insane, of the ones who could not speak for themselves before. Or better, could speak but would not be heard.

As a result, community-based services started to pop up with experiences in which the services and the mental health care were constructed with its users. The proposition of the reform was that the ones who had intensive psychic suffering would not have their whole lives determined by one specific health condition and would be assisted close to their community (Tenório, 2002; Nader, 2017). The mental health reform restructured mental health assistance and participation in two levels: 1) at the relationship between mental health workers and users, and 2) at the whole mental health assistance's organizational model.

Regarding the first level, the place that madness occupied in the relationship between therapist and patient was dislocated. Treatments started to be reorganized to open space for the humanity of mental health service users. The vertical separation between workers and users was blurred. Activities were conducted in ways that the mental health service

\footnotetext{
${ }^{5}$ Important international references in remodeling mental health assistance.

${ }^{6}$ There was a dislocation in naming: from patients to health service users, because they were more than "ill people" being treated, but were citizens who helped build the health system.
} 
workers and users could exchange knowledge amongst themselves. This included soccer or chess matches, movie discussions, book writing, museum excursions, freedom of circulation in general, therapeutic and non-therapeutic groups, town halls to review the service's organization and deliberate on problems and solutions. This new paradigm on the original psychiatric institution was inspired by the experiences of Tosquelles and Jean Oury in La Borde (Goldberg, 1996).

The second level led to radical changes in the organization of mental health assistance in Brazil. As a result of the strong advocacy of the Anti-asylum struggle movement, a Brazilian Law known as the Anti-asylum struggle Law was approved in 2001. It instituted that mental health assistance had to be community-based. This "arm" of change in assistance and participation was inspired by the Italian reform, represented mainly by Franco Basaglia (Goldberg, 1996).

Soon, new laws contributed to organizing this change in assistance, from which the Psychosocial Community Centers (Centro de Atenção Psicossocial - CAPS) were instated as the secondary attention for mental health. The primary attention happens in the Basic Health Units ${ }^{7}$, and the tertiary attention is based on general hospitals - rather than in the former psychiatric-only asylums. Different parts of the health network also became responsible for supporting mental health users who had long lived in psychiatric asylums, aiding them with their citizenship needs, such as residency, work, leisure, and their rights as citizens. Each CAPS counts with a multi-professional team that works together with each mental health service user in their Singular Therapeutic Project, built in composition. No more the only saying in the treatment would come from the doctor or the therapists.

Psychosocial attention in the Brazilian Mental Health Assistance context does not mean adapting a psyche to the social (Paiva, 2013). It is rather the opposite: considering the multiple determination between psychological and social determinations in the healthillness process (Capistrano et al., 2021) and exploring actions in the social to better nurture the encounter between the subject(-not-anymore-object) and the social. This perspective goes in line with the ethical posture that we saw in Freire and in these mobilizations we have approached so far. It is connected to the type of participation that Freire proposed, and it furthers the effort of distancing Mental Health practices from the Mental Hygiene Services presented at the beginning of this text. Participation is not to improve rapport or to "help" the marginalized. The participation itself is a fundamental element for the whole society to be more. In the case of the Mental Health Reform, a person being able to be a citizen meant every person not running the risk of having their citizenship denied.

As the Mental Health Reform, the Sanitary Reform gained boost and dislocations when the population joined the discussion. Since the 1970s, two associations (Cebes and Abrasco) composed mainly of Health workers and academics were at full mobilization to construct a critical position about the public health system and formulate new models of a Health System. Cebes (Brazilian Center for Health Studies) was committed to spreading

\footnotetext{
${ }^{7}$ Primary Health Unit in the Brazilian Health System is the most frequent type of health service in Brazilian territory. They are divided along the neighborhoods so that each Unit is responsible for the primary health care of approximately 12,000 people. Primary Health Units are more "generalist" units, in which all residents in that specific territory location are seen by primary health care teams and can participate in prevention and health promotion actions. If there is a need for a more intensified and prolongued treatment, residents are referred to specific secondary units, such as the CAPSs in the case of mental health. The tertiary attention in the health system is usually used when an existing health condition requires intensified treatment, with few actions dedicated to prevention.
} 
the Collective Health discussions that emerged from academia to society. They fueled debates, meetings, books and magazines on the democratization of health (Paim, 2007).

Cebes' magazine was called Saúde em Debate (Health in debate), and their second issue, in 1977, contained an editorial arguing that health is a citizen's right, mentioning the need for a "sanitary reform". This is when the proposition of the Sanitary Reform was born (Paim, 2007); a proposition that had its first actions aligned with its positions: not keeping the good ideas in academia, but spreading it.

By the beginning of the 1980s, Brazil started a democratic transition that culminated in a civil presidency by indirect elections in 1985. Actors identified with democratic policy started to gain terrain in the government. Amongst them, Sérgio Arouca became the president of Fiocruz ${ }^{8}$. Debates and discussions on a more equitable health system started to gain place in legislature debates. The financing of the public health system and how welfare would be administered were at the center of the debate (Paim, 2007). The proposition of transferring the working Health System of the time - which only assisted the employed population, using their wages contributions - to the Ministry of Health was denied. The justification from the central government was: "this decision belongs to the workers". Sérgio Arouca, in response, decided that the $8^{\text {th }}$ Health Conference would call workers from the whole country to participate (Arouca, 2002 apud Paim, 2007).

Workers were called in all possible types of communication (Ensp Fiocruz, 2016). Registration for participation in the $8^{\text {th }}$ Health Conference was open to every civil society association. The communication team from the $8^{\text {th }}$ Conference even announced the call for registration on a famous soap opera of the moment: the priest character of the soap opera dedicated some minutes in the show to publicize it (Ensp Fiocruz, 2016). The result was 4,000 people, 1,000 elected delegates, and 98 working groups. The delegates came from all regions and social classes, and the debates could last several hours. The three main subjects were "health as an inherent right of the citizen, reorganization of the national health system, health system finances" (Paim, 2007, p. 92). The resulting reports from these working groups composed the $8^{\text {th }}$ Conference Final Report, which guided the discussions and the writing of the new Brazilian democratic Constitution, approved in 1988 (Paim, 2007). The Brazilian Constitution states that health is a citizen's right and, consequently, a State's duty.

The result was the Brazilian SUS (Unified Health System - Sistema Único de Saúde), a system with universality, equity, and integrality as its three main principles. Today, anyone who seeks health assistance in Brazil has the right to it. No bill is received for any procedure by the users. Ambulances, HIV treatment, sanitary vigilance, alternative practices, vaccination, health promotion actions, primary care, and high complexity procedures are free for the population.

\section{Discussion: today's open challenges}

After the Mental Health Reform ${ }^{9}$ accomplishments in the 1990s, 2000s, and 2010s, public mental health policies in Brazil are mainly guided towards social inclusion and consider the multi-determination of mental health suffering. Mental health services for infants and adolescents dedicate an essential part of services to intersectoral actions for better inclusion and well-being (Taño \& Matsukura, 2019; Penalva, 2020). In Public Health, Brazil has considerably decreased infant mortality (Leal et al., 2018) and mortality from

\footnotetext{
${ }^{8}$ Fiocruz is the main public health research institution in Brazil.

${ }^{9}$ That is still ongoing and struggling with backlashes in the last few years (Vincentin \& Blikstein, 2019)
} 
infectious and parasitic illnesses since the beginning of SUS (Paes \& Silva, 1999). Even though SUS has had many conquers and is an overcome itself, thanks to the popular participation and a posture of dialogue with the population in similar ways to what Freire proposed, many improvements and revisions must be pursued. We list some of them below.

First, Mental health workers that had a formation marked by the Mental Health Reform usually dedicate discussions and practices to not marginalize service users nor silence their existences with categorizations or diagnostics. Nonetheless, the urge for practices that are more connected to a democratic relationship with mental health users doesn't always reflect in the relationship with workers from other sectors. Teachers in the public education sector can often refer students to the CAPSs, asking for categorizations or justifications of why a student does not learn and, sometimes, there can be some dispute over the right way to proceed (Penalva, 2020).

Regarding the steps Freire used in the alphabetization of adults, Freire argued for the constant supervision of one to guarantee this one would not become the oppressor or silence the other. Nonetheless, this supervision has to be done with dialogue. The education sector itself in Brazil did not go through the same process of Reforms with the population participation as the health sector did. Public health workers have justification for having some space on their agendas for social participation or multi-professional team meetings, while education workers do not have the same possibility (Penalva, 2020). Giving support to think of better inclusion strategies inside the classroom, and not just away, in the clinic, may bring interesting outcomes for children, as Portugal's experience indicates (Rodrigues, 2001).

There is a need to develop better intersectoral actions amongst the different sectors to guarantee qualified public sector actions towards equity. The ethical position that dialogues with the alterity and searches to understand multicausality in how things are has to be present in the relation with other workers as well.

Second. Social participation is a SUS's working engine. Every Health Unit has its Management Council, composed of $50 \%$ by their users, $25 \%$ by workers, and $25 \%$ by the Unit's directory. The Unit's Councils are gathered in Regional and Municipal Councils. Regional and Municipal Councils are gathered and represented in the State Council and, at last, a National Health Council. The National Health Council is still active and has helped the system to resist different attacks ${ }^{10}$. Other sectors have similar functioning, inspired by SUS (Oliveira \& Kahhale, 2020).

Nonetheless, the institutionalization of these Councils has voided some of the transformation potential in these places, with tasks occasionally becoming bureaucratic. Also, experts (Gershman, 1995; Paim, 2007) point out that the health reform was partial because some propositions were lost along the way, as has popular participation for the major decisions. There are still inequities to be corrected, and the State is constantly proposing changes to SUS that favor private corporation's interests. Health users that have the time to participate in Councils usually have specific profiles, considering that most of the population is constantly juggling between different jobs and family responsibilities

\footnotetext{
${ }^{10}$ For instance, in 2017, The Health Councils prevented São Paulo's mayor, Dória, from closing the pharmacies in the Primary Health Units to offer medication assistance through a partnership with private pharmacies. The main problem in this proposition, amongst many, was that there are regions that lack private pharmacies and rely mainly in the Primary Health Units' pharmacies. Private entities do not need to consider the population need and equal distribution of resources as the Public Sector does.
} 
(Penalva, 2020). In a country that is still deeply unequal (Souza \& Medeiros, 2017), Council participation is not enough anymore. This does not mean that Councils do not fulfill an important role. Solutions in a dynamic context will not be constant. There is the need for constant reviewing to not fall into other ways of silencing change.

Reinvent participation is urgent so that the Public Service - including Education - can be indeed for the public. It only makes sense for the Education sector to create and invent new types of participation if other parts of the Public System, such as Health, guarantee possibilities of legitimate participation. On the other hand, creating institutionalized political participation spaces without constructing experiences of emancipatory political participation in education can collaborate with the maintenance of what makes an unequal system (Saviani, 2012).

Besides the factors we previously highlighted from Freirean ethical posture for participation-building ${ }^{11}$, Freirean experiences and the history we brought so far can yet point to one more direction. For Freire, education is done through the mediation of the world, through solving problems we live (Shaull, 2006), not through static boxes of knowledge. Boxes of knowledge (math, science, Portuguese, etc.) help solve the world's problems, not the opposite. Nonetheless, our sectors separated as they are (Health, Education, etc.) are abstract separations of the world - during the first Brazilian cases told in this bibliographic review, for example, education and health matters were in the same Ministry -.

Today, the Participation Councils of each social sector have a crucial role in protecting citizen's rights. Nonetheless, intersectoral political participation spaces could be one alternative to reach the population that is now struggling with increasing unemployment, poverty, and hunger rates (Neves et al., 2021). As an alternative to only separating the citizens' political participation in each Council, we propose that intersectoral participation spaces can be interesting devices to hear the population's most urgent inputs. In this sense, it would be interesting to further investigate the strengthening of intersectoral action and participatory intersectoral actions to build the public sector as a result of citizen act and, hopefully, drive change towards diminishing inequalities in Education and other social sectors.

Renata Penalva is a psychologist with master's in Neuroscience and Education (Teachers College - Columbia University) and in School Psychology and Human Development (Psychology Institute - University of São Paulo). Currently works as a Study Coordinator at the NEED Lab (Teachers College) for the Baby's First Years Study and as a researcher at Instituto Veredas. Email: re.penalva@gmail.com

Adriana Marcondes Machado is a Professor of undergraduate and postgraduate courses at the Psychology Institute of the University of São Paulo (IP-USP) and Coordinator of the School Psychology Service at IP-USP. Coordinator, since 2019, of the Contemporary Subjectivity Working Group of the National Association for Research and Graduate Studies in Psychology in Brazil.Email:adrimarcon@uol.com.br

\footnotetext{
${ }^{11}$ 1)Considers social determinants of the phenomena that happens to an individual, and 2) requires constant effort to not fall for the tempting silencing of one's existence and full citizenship in order to build political participation, hence, build the public service with the population.
} 


\section{References}

Angelucci, C. B. (2014). Medicalização das diferenças funcionais-continuísmos nas justificativas de uma educação especial subordinada aos diagnósticos. Nuances: estudos sobre Educação, 25(1), 116-134.

Aguiar, K. F. D., \& Rocha, M. L. D. (2007). Micropolítica e o exercício da pesquisaintervenção: referenciais e dispositivos em análise. Psicologia: ciência e profissão, 27, 648-663.

Arouca, S. (1975) O Dilema Preventivista - Contribuição para a Compreensão e Crítica da Medicina Preventivista da Medicina Preventiva. http: / / www.cesteh.ensp.fiocruz.br/sites/default/files/o_dilema_preventivista. pdf

Birman, J. (2005) A Physis da saúde coletiva. Physis, 15, 11-16.

http: / / www.scielo.br/scielo.php?script=sci_arttext\&pid=S0103733120050003000 $02 \& \operatorname{lng}=\mathrm{en} \& \mathrm{nrm}=\mathrm{iso}$.

Brasil (1988). Constituição da República Federativa do Brasil: promulgada em 5 de outubro de 1988. Art.196.

Brasil (2002) Portaria GM/MS n. 336, de 19 de fevereiro de 2002. http: / / www.saude.mg.gov.br/images/documentos/Portaria_336.pdf.

Bueno, J. G. S. (1993) Educação especial brasileira: integração/segregação do aluno diferente - São Paulo: EDUC.

Campos, R. H. F. (2009). Helena Antipoff: psicóloga e educadora: uma biografia intelectual Rio de Janeiro: Fundação Miguel de Cervantes.

Capistrano, A., Carvalho, M., Vahdat, V., Boeira, L. (2021) Caminhos em Saúde Mental Instituto Cactus.

Costa, J.F. (1980) História da psiquiatria no Brasil: um corte ideológico (3rd ed.) - Rio de Janeiro: Campus, 1980.

Dunker, C.I.L. \& Kyrillos, F.N. (2015) Psicanalise e Saúde Mental. Porto Alegre: Criação Humana

Ensp Fiocruz (2016) - "Oitava: a conferência que auscultou o Brasil". https: / / www.youtube.com/watch?v=zZAHdF0fNps

Feinstein, L. (2003). Inequality in the early cognitive development of British children in the 1970 cohort. Economica, 70(277), 73-97

Freire, P. (1987). Pedagogia do Oprimido. Editora Paz e Terra.

Freire, P. (2003). Educação como prática da liberdade. Editora Paz e Terra.

Freitas (2009) A criança problema: formas de coesão contra o pobre e formas partilhadas de preterição social In: Mota, A., Schraiber, L.B. (Eds) Infância e Saúde: perspectivas históricas. -Hucitex/Fapesp 
Foucault, M. (2002). Em defesa da sociedade. Curso no Collège de France (1975-1976).

Garcia, R.A.G. (2014) Arthur Ramos e Durval Marcondes: higiene mental, psicanálise e medicina aplicadas à educação nacional (1930-1950). Educação E Sociedade, 35(128), 629-996).

Gershman (1995). A Democracia Inconclusa: Um Estudo da Reforma Sanitária Brasileira. Editora Fiocruz.

Glaeser, E. L., Ponzetto, G. A., \& Shleifer, A. (2006). Why does democracy need education? Journal of economic growth, 12(2), 77-99.

Goldberg, J. (1996). A clínica da psicose: um projeto na rede pública. Te Corá.

Januzzi, G.S.M. (2012) A educação do deficiente no Brasil: dos primórdios ao início do século XXI, Autores Associados

Leal, M. D. C., Szwarcwald, C. L., Almeida, P. V. B., Aquino, E. M. L., Barreto, M. L., Barros, F., \& Victora, C. (2018). Saúde reprodutiva, materna, neonatal e infantil nos 30 anos do Sistema Único de Saúde (SUS). Ciência E Saúde Coletiva, 23, 1915-1928. https: / / doi.org/10.1590/1413-81232018236.03942018

Machado, A. M. (1996). Reinventando a avaliação psicológica (Doctoral dissertation, Universidade de São Paulo).

Machado, A. M. (2016) Psychological Evaluation: A practice articulated with the creation of norms of existence. In: Souza, M. P. R.; Toassa, G.; Bautheney, K. C. (Eds.) Psychology, Society and Education: Critical Perspectives in Brazil. New York: Nova Publishers, 2016. ISBN: 978-1-63484-882-4

Marfinati, A. C., \& Abrão, J. L. F. (2014). Um percurso pela psiquiatria infantil: dos antecedentes históricos à origem do conceito de autismo. Estilos da clínica, 19(2), 244-262.

Mello, J. A. C., Valla, V.V. (1986) Sem Educação ou Sem Dinheiro?. In: Minayo, MCS (org) A Saúde em Estado de Choque. Rio de Janeiro: Editora Espaço e Tempo e FASE, 1986. P. 21-35)

Mendes, E.G. (2010) Breve histórico da educação especial no Brasil. Revista Educación y Pedagogía, 22(57).

Muller, T.M.P. (2000) A primeira escola especial para crenças anormais no Distrito Federal: o Pavilhão Bourneville (1903-1920). Revista Brasileira de Educação Especial, Marília: Unesp, 6(1), 79-97.

Nader, A.R. (2017) Entre a negação do manicômio e a afirmação de um modelo comunitário: fabricando formas de luta. (Master's Dissertation - Instituto de Psicologia, Universidade de São Paulo) 
Neves, J. A., Machado, M. L., Almeida de Oliveira, L. D., Moreno, Y. M. F., de Medeiros, M. A. T., \& de Vasconcelos, F. D. A. G. (2021). Desemprego, pobreza e fome no Brasil em tempos de pandemia por Covid-19. Revista de Nutrição, 34, e 200170.

Navarro, D. (2010) Psiquiatria y Nazismo. Ediciones Madres de Plaza de Mayo.

Nicolas, S., Andrieu, B., Croizet, J. C., Sanitioso, R. B., \& Burman, J. T. (2013). Sick? Or slow? On the origins of intelligence as a psychological object. Intelligence, 41(5), 699-711.

Oliveira, P. A., \& Kahhale, E. M. S. P. (2020). Uma história do Sistema Único de Assistência Social (SUAS), a participação do psicólogo e possibilidades de atuação. Revista Psicologia Política 20(47), 119-131.

Paes, N. A., \& Silva, L. A. A. (1999). Doenças infecciosas e parasitárias no Brasil: uma década de transição. Revista Panamericana de Salud Pública, 6, 99-109. https: / / www.scielosp.org/pdf/rpsp/1999.v6n2/99-109/pt

Paim, J.S. (2006) Desafios para a Saúde Coletiva no Século XXI - EDUFBA.

Paim, J.S. (2007). Reforma Sanitária Brasileira: Contribuição para a Compreensão e Crítica. https: / / repositorio.ufba.br/ ri/bitstream/ ri/10376/1/5555555555.pdf

Paim, J.S. \& Almeida Filho, N. (1998). Saúde coletiva: uma "nova saúde publica" ou campo aberto a novos paradigmas? Rev. Saúde Publica. 32(4), 299- 316. https: / / doi.org/10.1590/S0034-89101998000400001.

Paiva, V. S. F. (2013). Psicologia na saúde: sociopsicológica ou psicossocial? Inovações do campo no contexto da resposta brasileira à AIDS. Temas em Psicologia, 21(3), 531549 .

Patto, M. H. S. (1990). A produção do fracasso escolar: histórias de submissão e rebeldia. TA Queiroz

Patto, M.H.S. (2017) Para uma crítica da razão psicométrica. In: Machado, A; Lerner, A., Fonseca, P. (orgs). Concepções e proposiçoés em Psicologia e Educação. Blucher

Penalva, R.V.S. (2020). Caps IJ e escolas: a necessidade de encontros nas diferenças. (Master 's Dissertation, Instituto de Psicologia, Universidade de São Paulo). https: / / www.teses.usp.br/teses / disponiveis / 47 / 47131 / tde-03082020113938 / pt-br.php

Rede Brasil atual (2017) - Pressionado, secretário de Doria recua e agora afirma que não fechará farmácias do SUS.https:// www.redebrasilatual.com.br/saude-eciencia/2017 / 04/ pressionado-secretario-de-doria-recua-e-agora-afirma-que-naofechara-farmacias-do-sus /

Rivera, F. J.U. (1989). Planejamento de saúde na América Latina: revisão crítica. In: Rivera, F.J.U. Planejamento e programação em saúde: um enfoque estratégico. Cortez / ABRASCO; 11-55. 
Rodrigues, D. (2001). Educação e diferença: valores e práticas para uma educação inclusiva.

Saviani, D. (2012) Escola e Democracia (42nd ed.). Autores Associados.

SescTC, 2020, Paulo Freire, Um Homem do Mundo, by Cristiano Burlan. Available in: https: / / sesctv.org.br/ programas-e-series / paulo freire / ?mediaId=000429cb1923a0e36 3b4c42ae4bcd799

Shaull, R. (2006). Foreword to Pedagogy of the oppressed, by P. Freire. New York: Continuum.

Silva, J. R. D., Maniglia, F. P., \& Figueiredo, G. L. A. (2020). Paulo Freire e Edgard Morin na pós-graduação: perfil e percepções de egressos de um programa de pósgraduação em Promoção da Saúde. Revista Brasileira de Educação, 25.

Souza, P. H. G. F., \& Medeiros, M. (2017). The concentration of income at the top in Brazil, 2006-2014 (No. 163). Working Paper. https: / / www.econstor.eu/bitstream/10419/200604/1/1008746088.pdf

Taño, B.L.; Matsukura, T.S. (2019) Intersetorialidade e cuidado em saúde mental: experiências dos CAPSij da Região Sudeste do Brasil. Physis, 29(1). https: / / doi.org/10.1590/ s0103-73312019290108.

Teixeira, A. (1956). A escola pública universal e gratuita. Revista Brasileira de Estudos Pedagógicos, 26(64), 3-22

Verzolla B.L.P. (2017) Medicina, saúde e educação: o discurso médico-eugênico nas teses doutorais da Faculdade de Medicina e cirurgia de São Paulo entre 1920 e 1939 (Master's Dissertation, Med. Preventiva - Universidade de São Paulo)

Tenório, F. (2002). A reforma psiquiátrica brasileira, da década de 1980 aos dias atuais: história e conceitos História, Ciências, Saúde-Manguinhos, 9, 25-59.

Westin, R. (2016, November 8). Por 100 anos, analfabeto foi proibido de votar no Brasil. Agência https: / / www12.senado.leg.br/noticias / materias / 2016/11/04/ por-100-anosanalfabeto-foi-proibido-de-votar-no-brasil

Wilson, David N. (1994). Comparative and international education: Fraternal or Siamese twins? A preliminary genealogy of our twin fields. Comparative Education Review, 38(4), (pp.449-486).

Zancan, L., \& Matilda, Á. H. (2015). Trajetórias de Joaquim Alberto Cardoso de Melo: Quincas, um berro à vida. Ciência $\mathcal{E}$ saúde coletiva, 20, 32753282.https: / / dx.doi.org/10.1590/1413-812320152010.14622015. 